\title{
ANALÝZA POSTUPU PRÁC ZOSILNENIA STENY
}

\section{ANALYSIS OF THE WALL STRENGTHENING WORK PROCEDURE}

\author{
Ing. Marek Ďubek, PhD. ${ }^{1 *}$; doc. Ing. Peter Makýš, PhD. ${ }^{1}$ \\ ${ }^{1}$ STU v Bratislave, Stavebná fakulta, Radlinského 11, Bratislava 810 05, Slovensko \\ *korespondenční autor: marek.dubek@stuba.sk
}

\begin{abstract}
ABSTRAKT CZ
Harmonogramy majú uplatnene prevažne v plánovaní stavby. Môžu slúžit' však aj ako kontrola skutočne zrealizovaných prác a overenie nasadenia pracovníkov. Článok popisuje jeden skúšobný harmonogram v procese po realizácii prác na stanovenie maximálního skutočne potrebného počtu odpracovaných hodín pracovníkmi. Analýza preukázala sumu hodín, ktorú nebolo potrebné prekračovat' a preto ani náklady na túto prácu nemohli byt’ vyššie.
\end{abstract}

Klíčová slova: Harmonogram, BIM, produktivita práce, normohodina

\section{ABSTRACT}

The schedules are used mainly in construction planning. However, they can also serve as a check of the actually performed work and verification of the commitment of workers. The article describes one test schedule in the process after the implementation of work to determine the maximum actually required number of hours worked by workers. The analysis showed the amount of hours that did not need to be exceeded and therefore the cost of this work could not be higher.

Key words: Schedules, BIM, working productivity, standard hour

\section{1 ÚVOD}

Časové plánovanie slúži prioritne na plánovanie prác, ktoré s budú vykonávat'. Časovému plánovaniu je potrebné venovat' dostatočnú pozornost' pred výstavbou, pred zúčastnením sa verejných zákaziek, pri tvorbe ponukových podkladov, kde je harmonogram jednou z podmienok [1]. Je to podklad pre zhotovitel’a a zároveň stavebníka - investora. Účastníci výstavby z neho vyčítajú termíny - mílniky a vedia sa tak pripravovat' na d'alšie či už technologické, ekonomické alebo personálne nastavenie výstavby. Najpoužívanejšia forma v stavebníctve v súčasnosti je harmonogram v tvare Ganttovho grafu. Harmonogram má ale pre investora zásadnú informáciu, ktorou sú termíny. Termíny sa obvykle premietajú do zmluvy a jej podmienok, kde sa zvyčajne nachádzajú len dva hlavné údaje a tými sú začiatok výstavby a koniec. Článok sa zaoberá súčasnými možnost’ami tvorby časových plánov v IT prostredí a čerpaním podkladov pri ich tvorbe.

Pri tvorbe harmonogramov „d’alej HMG“ sa vychádza z priestorovej štruktúry objektu, organizácie v priestore a v čase [2], navrhovanej technológie, časovej postupnosti navrhnutých technológií $\mathrm{s}$ ich technologickými prestávkami potrebnými pre d’alšie etapy a práce. Stavebné spoločnosti prispôsobujú časové harmonogramy svojim kapacitám a vlastným technológiám, použitel'ným počas výstavby. V 
časovom plánovaní sa jedná prevažne o koordináciu pracovníkov, materiálu, strojov, zariadení a nakupovaných služieb [3;4].

\subsection{Zdrojové údaje pre tvorbu harmonogramu}

Pri tvorbe normohodín sa použivajú nasledovné metódy:

1. metóda skúmania skutočnej spotreby času, v rámci ktorej sa vykonávajú:

- $\quad$ snímky pracovného dňa (zmeny),

- $\quad$ snímky operácií,

- momentové pozorovania,

- $\quad$ snímky využitia stroja.

2. metóda určovania normovatel'nej spotreby času:

- $\quad$ rozborové metódy (výpočtová, chronometrážna, porovnávacia),

- sumárne metódy (štatistická metóda, sumárny odhad, sumárna porovnávacia metóda, metóda sumárnych empirických vzorcov).

Normohodiny sú tvorené na základe sledovania procesu a vyhodnocovania času. Na trhu sú dostupné rôzne databázy, ktoré disponujú normohodinami. Patria sem databázy CENEKON, ODIS, CONTEC atd' $[5 ; 6]$.

\subsection{Podrobnosti a štruktúra harmonogramu}

Podl'a podrobnosti členenia činností, podl'a zvolenej časovej jednotky a podla časového horizontu sa rozdel'ujú časové plány do niekol'kých stupňov:

- $\quad$ strategický - mílnikový časový plán spracovávaný na celý priebeh projektu výstavby. Stanovuje lehoty realizácie jednotlivých hrubých a čiastkových fáz výstavby (najmä zmluvné termíny). Mal by slúžit' obchodnému vedeniu stavebníka. Časová jednotka je väčšinou mesiac alebo štvrt'rok.

- $\quad$ koncepčný - koncepčný plán realizácie stavebného diela, spracovávaný v prípravnej fáze zákazky. Zostavuje sa na úrovni čiastkových fáz výstavby spravidla s mesačným členením.

- $\quad$ realizačný - prehl’adný časový plán pre taktické riadenie realizácie výstavby. Je určený pre vedenie projektu s časovou jednotkou mesiac alebo týždeň.

- $\quad$ koordinačný - časový plán slúži pre potreby operatívneho riadenia, teda na vedenie a kontrolu technologickej alebo stavebnej časti objektu. Spracováva sa samostatne pre jednotlivé hrubé alebo čiastkové fázy výstavby. Časová jednotka týždeň alebo deň.

\subsubsection{Využitie softvérov $v$ riadení výstavby}

V súčasnosti je na trhu niekol'ko programov na tvorbu časových plánov. Každý ponúka rôzne pracovné prostredie a možnosti. Jednotlivé programy majú pre využitie v stavebníctve rôzne výhody ale aj nevýhody. Ich použitel'nost' je individuálna $\mathrm{v}$ závislosti od požiadaviek tvorcu harmonogramu, typu a charakteru stavby a požadovaných výstupov z harmonogramu [7].

Medzi najpoužívanejšie programy na tvorbu a úpravu harmonogramov patria:

- $\quad$ PRIMAVERA

- Microsoft Project

doi.org/10.51704/cice.2020.vol6.iss2.pp34-40

ISSN (online) 2336-7148

www.cjce.cz 
- $\quad$ Project Planner

- $\quad$ CONTEC

- Power Project

- Cenkros

- Kalkulus

- $\quad$ a d’alšie....

Význam harmonogramov spočíva aj v kontrole už zrealizovanej stavby, kedy sú potrebné overovania vykázaných hodín, rozsahu prác a overovanie splnenia zmluvného časového plánu. Riešenie konkrétnej stavby uvádzame v článku d’alej.

\section{APLIKÁCIA HMG}

Pri tvorbe harmonogramu pre stavbu „Vzorová stavba - realizácia steny“ bola využívaná súbežná a postupná metóda atomických činností (V grafickej časti sú jednotlivé procesy vykreslené v ich postupnosti. Väzby použité v harmonograme: FS - „Finish - Start“; FF - „Finish - Finish“; SS - „Start - Start"). Záber prezentuje časové obdobie a vzt’ahuje sa na realizáciu steny a prievlaku, kedy bude na každú činnost' (okrem materiálu) použitý a maximálne nasadený počet pracovných jednotiek v súlade so zákonom č. 311/2001 (Z.z. Zákonník práce podl’a $\S 85$ a $\S 86$, kde je určené, že pracovný čas v priebehu 24 hodín nesmie presiahnut' osem hodín a pracovný čas zamestnanca je najviac 40 hodín týždenne), pričom nebude nasadenie pri vybraných (časovo a technologicky náročných) činnostiach $\mathrm{v}$ režime dvojsmennej prevádzky. Pri plánovaní pracovníkov je dodržané nasadenie neprekračujúce dovolené napätie práce pri vykonávaní činností, ktoré je podporené a určené z pracovných normohodín (výkonové normy a normy prácnosti) dostupných z verejne publikovaných periodík [8] alebo databáz (CENEKON II/2019; CONTEC, údaje výrobcov zariadení) a zo sledovania vlastných pracovných nasadení alebo momentkového sledovania $\mathrm{v}$ zmysle pravidiel tvorby normohodín.

Pri tvorbe harmonogramu sa vychádzalo z:

- $\quad$ Projektovej dokumentácie pre tvorbu hierarchického členenia stavby,

- $\quad$ Slepého rozpočtu s výkazmi, množstvami,

- Technologických predpisov a požiadaviek na použité stavebné materiály (bez ohl’adu na všetky potrebné technologické prestávky, vyzretia konštrukcií pri mokrých procesoch)

- Normových obmedzení (normohodiny, produktivita práce) - údaje do výpočtovej časti.

Celý časový plán je zobrazený formou Ganttovho diagramu s členením a rozpisom hierarchickej štruktúry činností WBS - (Work Breakdown Structure), a je rozdelený na dve časti. Jedna čast' je výpočtová a druhá čast' je grafická - pozri obr 1. Výpočtová čast' spracováva vložené údaje $\mathrm{s}$ množstvami jednotlivých činností a normohodinami, ktoré vyhodnocuje a určuje trvanie činnosti s počtom nasadených pracovníkov [9]. Trvanie činnosti (mierka pre zobrazenie sledu činností) je zobrazené $\mathrm{v}$ dňoch. Výpočtová čast' je celkovo rozdelená do niekol'kých stĺpcov. Prvé tri stĺpce sú informatívne (číslo riadku z predloženého výkazu výmer; kód položky a Názov položky). Prvý stĺpec za stĺpcom „Názov činnosti“ prirad’uje k činnosti mernú jednotku, druhý stĺpec určuje množstvo a tretí stĺpec udáva normovú prácnost' $\mathrm{v}$ Nh/M.J. Tieto údaje sú d'alej správnym naprogramovaním softvéru spracované a vyhodnotené. 


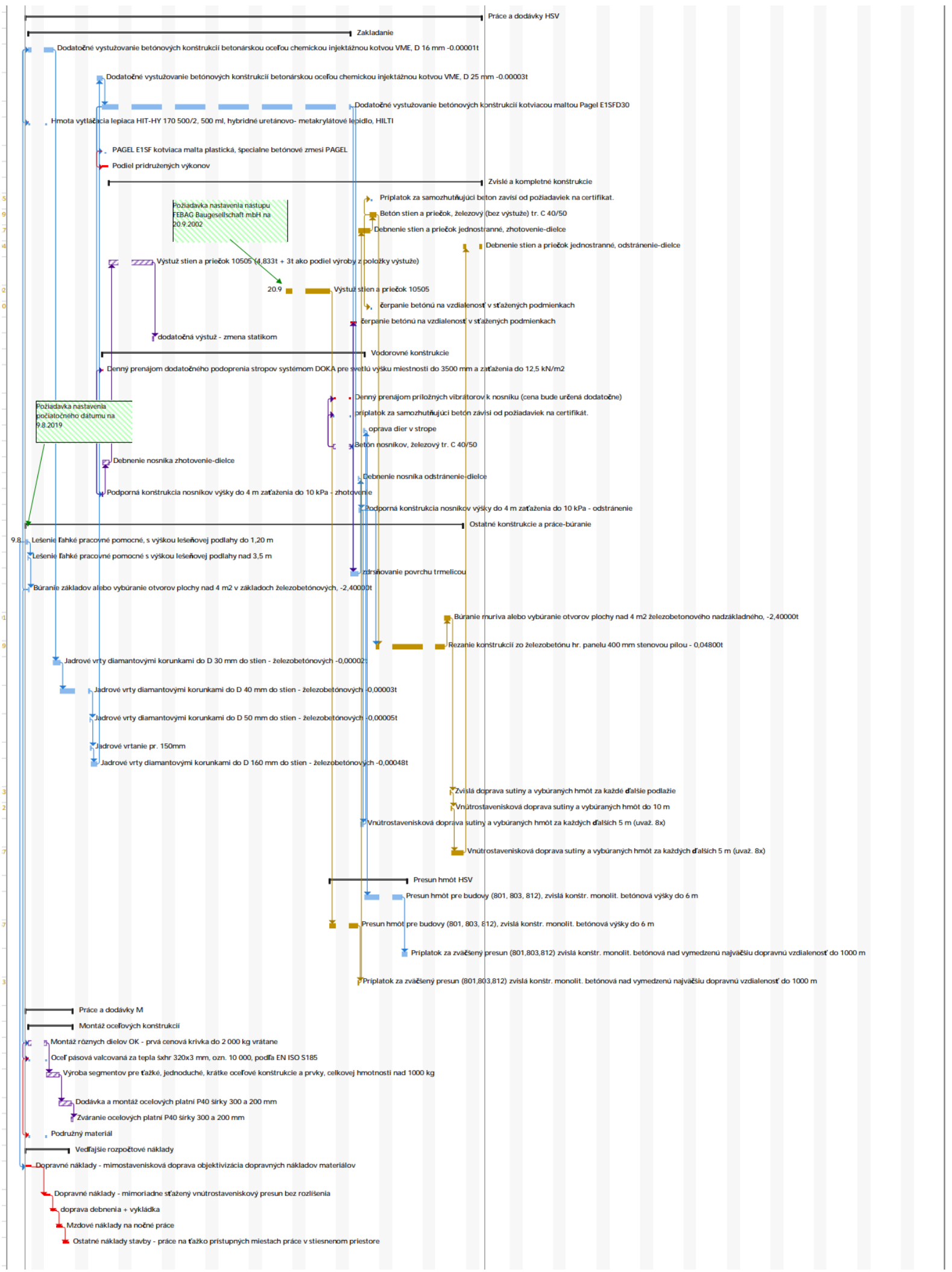

Obr. 1 Grafická čast' zostaveného harmonogramu 
Pri zostavovaní HMG je pre výpočtovú čast' potrebné poznat' alebo získat' normohodiny pre určenie trvania stavebného procesu. Ten sa vypočíta podl'a nasledujúceho vzt’ahu:

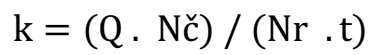

kde $\quad \mathrm{k}$ - trvanie stavebného procesu (zmena),

$\mathrm{Q}$ - množstvo produktu (m.j.),

Nč - normatív času, normohodina práce (Nh),

$\mathrm{Nr}$ - počet robotníkov HSV a PSV, t - počet mesiacov v sledovanom období.

Pri tejto fáze je pomocníkom podrobný výkaz výmer stavby. V súčasnosti možno považovat' databázu normohodín z CENEKON spoločnosti za podporné údaje pri tvorbe HMG. Pre analýzu postupu prác spätne bol zostavený harmonogram preukazujúci rozsah prác, zároveň boli práce konfrontované s predpísaným postupom: technickou správou a vytvoreným 3D projektom s informáciami - BIM.

Podrobnost' BIM projektu bola aj v technologickej stránke. Okrem zabudovaných konštrukcií boli spracované aj pomocné koštrukcie ako debnenie - pozri obr. 2a-2e.

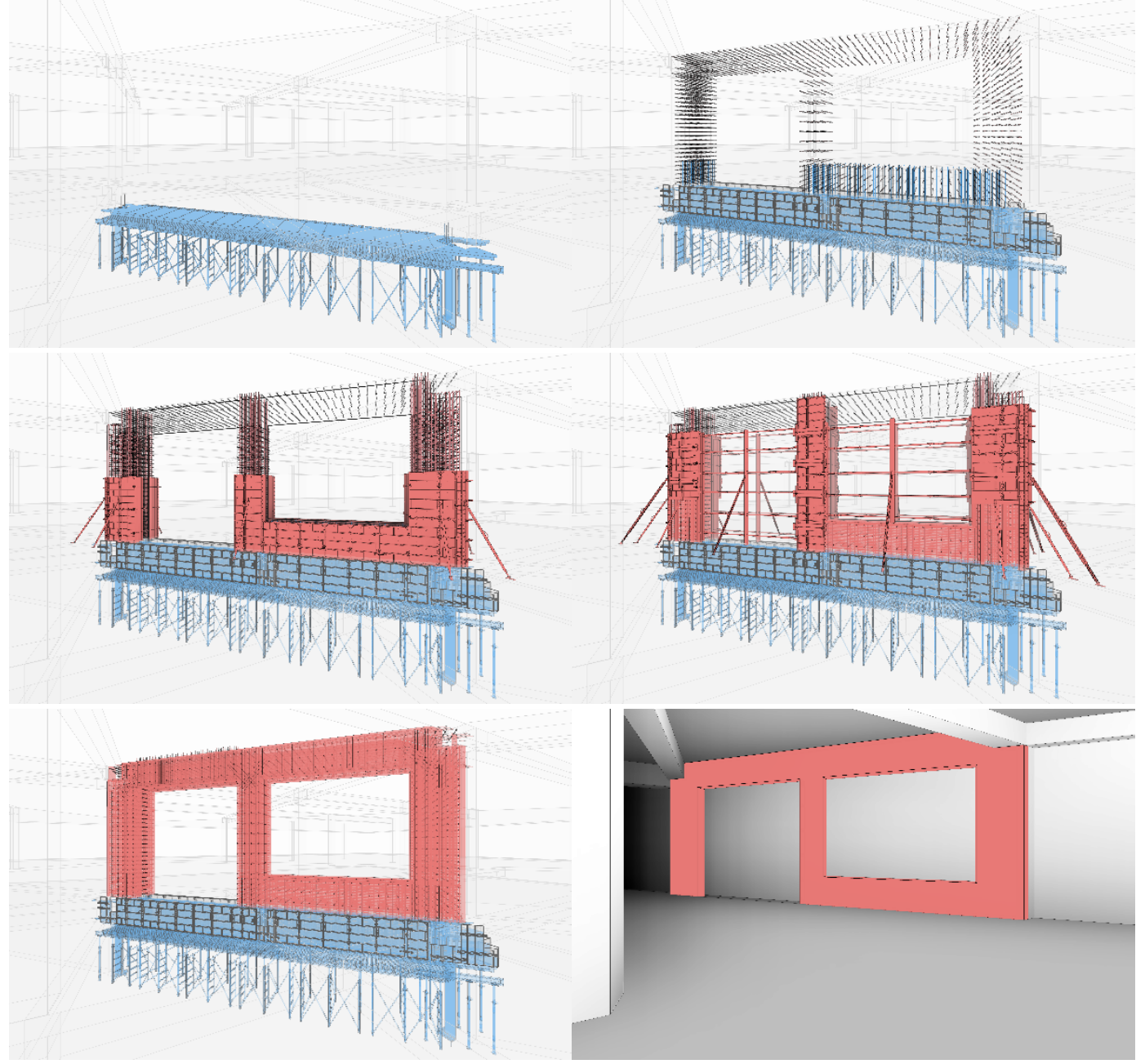

Obr. 2a - 2f Schéma postupu výstavby a realizácie dodatečného zosilnenia

Okrem časovej analýzy boli analyzované aj reálne odpracované hodiny, ktoré sú vykreslené na obrázku nižšie. 


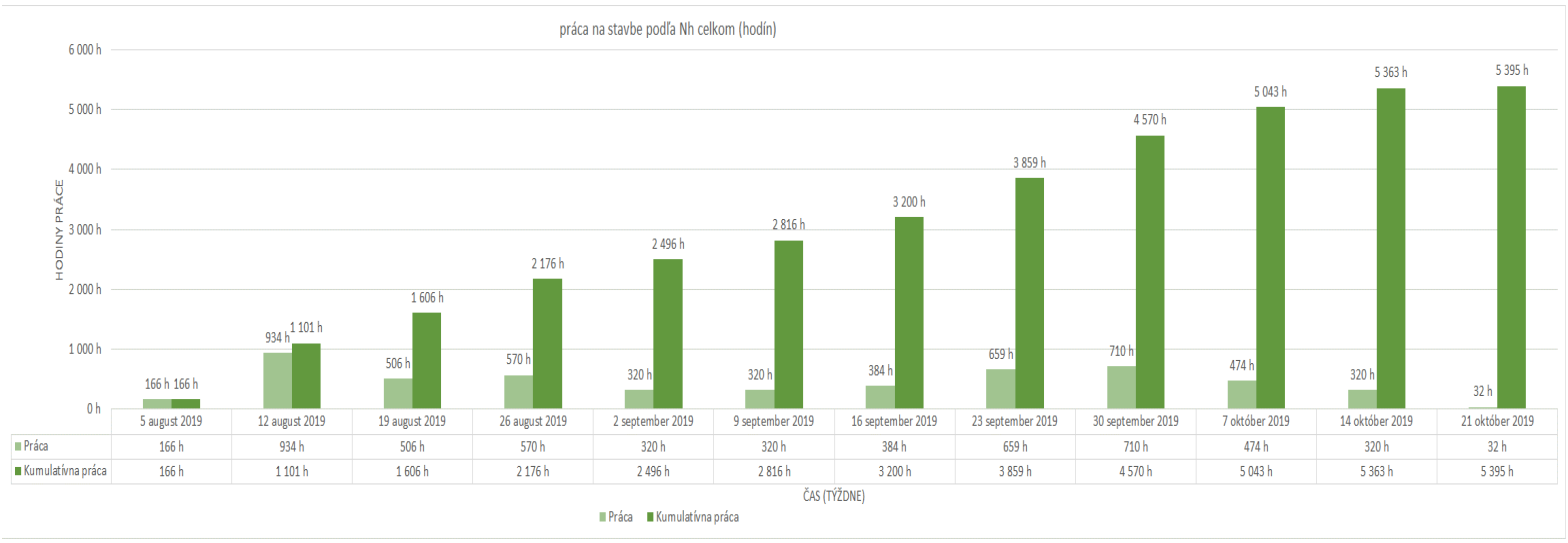

Obr. 3 Schéma postupu výstavby a realizácie dodatečného zosilnenia

\subsection{Výsledky}

Z HMG následne je možné tvorit' výstupy vo forme nasadenia pracovníkov. Každá činnost, ktorá je v grafickej časti harmonogramu zobrazená pruhom, má priradené zroje - pracovníkov. Ich súčet v priebehu dňa je potom možné vykreslit' vo forme histogramu alebo potrebného množstva odpracovaných hodín. Tie získáme z počtu pracovníkov a doby ich nasadenia. Na obrázku č. 3 sú zobrazené hodiny potrebné na spracovanie stavby spolu v týždňovom intervale. Spolu je potrebné na realizáciu diela podl’a normohodín čerpaných z databázy CENEKON 4526,27 hodín. Z analýzy pri nasadení rovnakého počtu pracovníkov v počte $8 \mathrm{ks}$ a pri napätí $75-95 \%$ spolu tvoria odpracované návrhové časy dokopy 5331,2 hodín, čo predstavuje zároveň maximálny akceptovaný strop času potrebného na realizáciu diela. Prekročenie počtu potrebných hodín môže bez odôvodnenia znamenat' nezvládnutie prác alebo technológie. Rozsah realizovanej práce podla dostupných normohodín je pri firme, ktorá stavbu realizovala 1142,54 hodín a pri firme, ktorá ju dokončovala je to 3380,3 hodín. Pri návrhu akceptovanej realizácie je potom podl'a analýzy v HMG možné uvažovat', pri napätí činností od $75 \%$ do $95 \%$, s rozsahom hodín pri firme ktorá stavbu realizovala v intervale 1376 hodín a pri firme ktorá stvbu dokončovala je to interval 3955,2 hodín. Prekročenie týchto navrhovaných hodín o +- 20\%, sa nedá bez opodstatnených okolností považovat’ za dobu na realizáciu prác ako primeranú.

\section{ZÁVER}

Využitie HMG je pri analýzách stavieb významné a ich závery môžu poslúžit pri záverečnom vysporiadaní. Analýza stavebných denníkov je náročný proces vyžadujúci dokonalé znalosti stavebných postupov, poznania projektovej dokumentácie a štandardných postupov podl'a technologických predpisov. Časová analýza aj v tomto prípade vlastne spätne vykreslila postup prác a možné varianty v kritických časových intervalech bez časovej rezervy a jednoznačne preukázala chronológiu a maximále náklady na prácu pri poznaní okrajových podmienok. Obdobné kontroly časových sledov činností sa využívajú hlavne pri sporoch, kedy na sporných stranách stoja investor a zhotovitel' a predmetom ich sporu je finačný pohl'ad na stavebný proces. Je potrebné pritom brat' $\mathrm{v}$ úvahu okrajové podmienky a zmluvné podmienky.

\section{Pod'akovanie}

Tento článok vznikol vd’aka podpore Vedeckej grantovej agentúry Ministerstva školstva, vedy, výskumu a športu Slovenskej republiky a Slovenskej akadémie vied pre projektu VEGA-1/0506/18. 


\section{Použitá literatura}

[1] ĎUBEK, Marek. Význam harmonogramov v kvalite výstavby a podklady $\mathrm{k}$ ich tvorbe, In: Almanach znalca, STU ÚSZ Bratislava, 2/2016.

[2] BAŠKOVÁ, Renáta. Časové plánovanie výstavby v programe MS Project, Vydavatel'stvo Univerzitná knižnica TUKE Košice. 2011. ISBN 978-80-553-0818-0.

[3] MAKÝŠS, Oto. a MAKÝŠ, Peter. Technologický projekt. Stavenisková prevádzka a zariadenie staveniska. Bratislava : Vydavatel'stvo STU, 2003. s. 203. ISBN 80-227-1847-5.

[4] KOZLOVSKÁ, Mária. Inovácie v oblasti systémov projektovania stavieb. In: Kvalita Inovácia Prosperita. roč. 12, č. 2. 2008, s. 19-26.

[5] DVOŘÁK, Drahoslav. Řízení projektů - Nejlepší praktiky s ukázkami v Microsoft Office, Computer Press, Praha. 2008. ISBN 8025118856.

[6] DVOŘÁK, Drahoslav. Microsoft Project 2013, Vydavatel'stvo Computer Press, Brno. 2013 ISBN978-80-251-3819-9.

[7] ŠRÁMEK, Juraj. Časové plánovanie, návody na cvičenia, Vydavatel’stvo EDIS. 2014. ISBN 978-80-554-0876-7.

[8] ŠÚSR. Stavebná produkcia, zamestnanci a mzdy v stavebných podnikoch SR, vydávaná Štatistickým úradom Slovenskej republiky .

[9] ŠRÁMEK, Juraj. Časové plánovanie, návody na cvičenia, Vydavatel'stvo EDIS. 2014. ISBN 978-80-554-0876-7. 